\title{
INDIKATOR KEBERHASILAN KINERJA PERUSAHAAN
}

Nama : POPY AMALIA PAVITRA

E-mail : $\quad$ s130119040@student.ubaya.ac.id

Entrepreneurial Orientation merupakan salah satu bagian dari pengukuran kinerja keberhasilan melalui inovasi, eksperimen, fleksibilitas, penekanan proaktif, inovatif, dan penemuan efek negatif dari resiko platform digital pada lingkup internasional usaha baru dan sebuah penawaran sumber keunggulan kompetitif berkelanjutan (Kim \& Cavusgil 2020). Selain itu Open Innovation membantu perusahaan meningkatkan kinerja inovasinya dengan melakukan akses ide dan pengetahuan baru di luar batasan mereka secara terbuka serta untuk mencegah resiko dengan mengurangi ROI yaitu sebuah konsep kegiatan strategi inovasi terbuka menjadikan sebuah alternatif dengan melibatkan karakteristik keuangan maupun non-keuangan (Elia et al., Leckel et al 2020). Yang Kemudian terdapat Risk Governance yang merupakan sebuah pernyataan yang mendekati manajemen resiko yang berguna untuk meminimalkan resiko pada perusahaan atau khalayak umum dengan karakteristik ketidakpastian, ambiguitas, dan kompleksitas yang melebihi batas sektor kebijakan.

Pada pendekatan partisipatif, Open Innovation lebih terdistribusi, dan desentralisasi pada proses pengembangan produk dengan sumber daya terbuka (Chesbrough 2003). Untuk kemudian Inovasi Terbuka ini disimpulkan pada penggunaan variable Struktur Jaringan (Network Structure), Kepercayaan, Pengembangan Produk (Product Development), dan Kinerja Perusahaan (Firm Performance) yang berperan penting pada UKM di efek mediasi sebagai elemen esensial dari kapabilitas pemasaran dalam mengelola inovasi dengan berbagai kompetensi untuk menghadapi kepentingan pada Open Innovation. Sumber daya terbuka yang merupakan modal sosial pada inovasi terbuka ini adalah Kepercayaan atau Trust guna menunjukan kualitas hubungan yang berinplikasi tuk mampu mengakses informasi dan sebuah dukungan (Pratono 2018b).

UKM lebih efektif dalam penerapan Risk Taking Behavior untuk memastikan adanya potensi dampak resiko dengan pendekatan proaktif karena berdampak positif bagi Firm Performance (Kinerja Perusahaan) dan memicu Pricing Capability (Kapabilitas Harga) yang kuat. Untuk mengukur adanya pengambilan resiko ini melewati 4 (empat) variabel yaitu Perilaku Pengambilan Resiko, Kinerja Perusahaan, Kapabilitas Harga, dan Turbelensi Teknologi Informasi (Pratono 2018a). 


\section{DAFTAR PUSTAKA}

Liaropoulus, A. S. (2020). Mengadopsi Tata Kelola Risiko dalam Industri Minyak Offershare dan dalam Konteks Budaya dan Geopolitik yang Beragam: Laut Utara VS Negara-negara Mediterania Timur. Safety Science, (120) 471-483.

Niemand, T. R. (2020). Digitalisasi dalam Industri Keuangan: Pendekatan Kontingensi Orientasi Wirausaha dan Visi Strategis Digitalisasi. European Management Journal.

Niu, Y. D. (2020). Effect of Entrepreneurial Orientation, Collectivistic. Industrial Marketing Management, (88) 35-46.

Pratono, A. H. (2018). Does firm performance increase with risk-taking behavior under information technological turbulence?: Empirical evidence from Indonesian SMEs. The Journal of Risk Finance, (19) 361-378.

Pratono, A. H. (2018). Network structure and open innovation : the role of trust in product development. Int. J. Business Innovation and Research, (15) 44-61.

Sengupta, A. \&. (2020). Impact of Open Innovation on Industries and Firms- A Dynamic. Technological Forecasting \& Social Change, (159) 120-199. 